\title{
Mineral composition of chicken meat floss produced from broilers fed diets with low
} energy levels

${ }^{1}$ Umar, A. M. and ${ }^{2}$ Mohammed, A.

${ }^{I}$ Department of Animal Health and Production, Binyaminu Usman Polytechnic, Hadejia, Jigawa State ${ }^{2}$ Department of Animal Health and Production, Federal Polytechnic, Bauchi

Corresponding author: auw.umar@gmail.com; +2348164727548

Abstract and +2348027374654

This study was designed to investigate the mineral composition of floss prepared from broiler chickens fed low energy diets. Three experimental diets comprising three energy levels of 2, 400 (A); 2, 600 (B) and 2, $800 \mathrm{ME} \mathrm{Kcal/Kg} \mathrm{(C)} \mathrm{were} \mathrm{formulated} \mathrm{and} \mathrm{fed} \mathrm{to} \mathrm{the} \mathrm{broiler}$ chickens. The crude protein of the starter and finisher diets were fixed at 24 and 20\%, respectively. A total of 270, one-day old Cobb 500 broiler chicks were weighed and randomly allocated to three treatments ( $A, B$ and $C$ ) of 90 birds per treatment, each treatment having three replications of 30 birds. At the end of eighth week, three birds were randomly taken from each replication for the preparation of meat floss. Triplicate samples of the raw and broiler chicken meat floss were analysed for calcium (Ca), magnesium (Mg), sodium (Na) and potassium (K). The experiment was laid in a Completely Randomized Design. Raw meat of broiler chicken fed diet containing 2, $800 \mathrm{ME} \mathrm{Kcal/Kg} \mathrm{had} \mathrm{the} \mathrm{highest} \mathrm{values} \mathrm{of} \mathrm{Ca}(50.72$ $\mathrm{mg} / \mathrm{Kg}), \mathrm{Na}(48.02 \mathrm{mg} / \mathrm{Kg})$ and $\mathrm{K}(80.96 \mathrm{mg} / \mathrm{Kg})$. Mineral composition of meat floss from broiler chicken fed diet containing 2, $800 \mathrm{ME} \mathrm{Kcal/Kg} \mathrm{had} \mathrm{the} \mathrm{highest} \mathrm{value} \mathrm{of} \mathrm{Na} \mathrm{(48.69}$ $\mathrm{mg} / \mathrm{Kg}$ ) and $\mathrm{K}(78.81 \mathrm{mg} / \mathrm{Kg})$. It is concluded that the raw meat and floss of broiler chickens fed diet containing 2, $800 \mathrm{ME} \mathrm{Kcal/Kg} \mathrm{had} \mathrm{highest} \mathrm{values} \mathrm{of} \mathrm{Na}$ and $\mathrm{K}$.

Keywords: Broiler chicken, meat floss, diets, energy levels and mineral composition

\section{Introduction}

In Northern Nigeria, Tsire, Balangu, Dambun-Nama (meat floss), Kilishi and Ragadada are the commonest meat products. The traditionally processed floss is highly acceptable to consumers because of its soft and tender taste compared to the hard and non-soft kilishi. Meat floss is easy to prepare and highly relished by consumers (Omojola et al., 2004). The product is mass consumed fast-food whose consumption is invariant with respect to ethnicity, religion, socio-economic factors or sex.

Meat floss is a Nigerian traditionally spiced, cooked, pounded, shredded and dried meat product which is commonly prepared using chicken meat, beef, chevon, mutton or camel meat and is popularly consumed in the Northern parts of Nigeria. The product appears to have developed as a means of preserving meat in the absence of facilities for refrigerated storage by the early Fulani and Hausa herdsmen (Igene et al., 1990). The growing importance of meat floss as an indigenous fast food makes it necessary to obtain information on its composition and to assess its nutritional contributions (Muhammad and Muhammad, 2007). The study was aimed to examine the mineral composition of chicken meat floss produced from broilers fed diets with low energy levels.

\section{Materials and methods \\ Description of the study area}

The experimental research was sited at the Poultry Demonstration Farm of the Department of Animal Health and Production, Binyaminu Usman Polytechnic, Hadejia, Jigawa State. The area is located in the sudan savannah zone of Nigeria, which lies between $10^{\circ} 02^{\prime}$ 2814 " E Longitude and $12^{\circ} 27^{\prime} 12.49$ ' $\mathrm{N}$ 


\section{Mineral composition of chicken meat floss produced from broilers}

Latitude. The town is served by Federal roads linking it to Nguru in the east, Kano in the northwest, Katagum in the south and Dutse (capital of the state) in the southwest. The old town has been extended beyond the traditional walls. Hadejia LGA is bordered on the south by Hadejia River, east by Kirikasamma LGA and north to west by Mallam-Madori LGA.

\section{Experimental diets containing varying energylevels}

Three experimental diets (A, B and C) containing three energy levels of 2, 400 (A), 2, 600 (B) and 2, $800 \mathrm{MEKcal} / \mathrm{kg}$ (C) were formulated and fed to the broiler chickens. The crude protein of the starter and finisher diets were fixed at 24 and $20 \%$, respectively. The ingredients and calculated chemical compositions of the starter and finisher diets were presented in Tables 1 and 2, respectively.

Table 1: Composition (\%) of poultry chicken starter experimental diets-

\begin{tabular}{|c|c|c|c|}
\hline \multirow[t]{2}{*}{ Ingredients } & \multicolumn{3}{|c|}{ Dietary Energy Levels (ME Kcal/kg) } \\
\hline & A & $\mathrm{B}$ & $\mathrm{C}$ \\
\hline Maize & 22.00 & 33.00 & 44.00 \\
\hline Soybean Meal & 24.00 & 26.00 & 29.00 \\
\hline Ground nut cake & 15.00 & 16.00 & 16.00 \\
\hline Wheat Offal & 33.00 & 19.00 & 5.00 \\
\hline Bone Meal & 3.00 & 3.00 & 3.00 \\
\hline Limestone & 2.00 & 2.00 & 2.00 \\
\hline Common Salt & 0.30 & 0.30 & 0.30 \\
\hline$*$ Premix & 0.25 & 0.25 & 0.25 \\
\hline Methionine & 0.25 & 0.25 & 0.25 \\
\hline Lysine & 0.20 & 0.20 & 0.20 \\
\hline Total & 100.00 & 100.00 & 100.00 \\
\hline \multicolumn{4}{|l|}{ Calculated Analysis } \\
\hline $\mathrm{ME}(\mathrm{Kcal} / \mathrm{kgDM})$ & 2417 & 2613 & 2810 \\
\hline Crude Protein $\quad(\%)$ & 24.00 & 24.00 & 24.10 \\
\hline Lysine $(\%)$ & 1.40 & 1.40 & 1.40 \\
\hline Methionine (\%) & 0.60 & 0.60 & 0.60 \\
\hline Calcium (\%) & 1.60 & 1.60 & 1.60 \\
\hline Phosphorus (\%) & 0.70 & 0.70 & 0.70 \\
\hline Crude Fibre (\%) & 5.60 & 4.80 & 4.00 \\
\hline Ether Extract (\%) & 3.80 & 3.90 & 3.90 \\
\hline
\end{tabular}
$200 \mathrm{mg}$, Zinc $30,000 \mathrm{mg}$, Antioxidant $1,250 \mathrm{mg}$

Table 2: Composition (\%) of poultry chicken finisher experimental diets

\begin{tabular}{|c|c|c|c|}
\hline \multirow[t]{2}{*}{ Ingredients } & \multicolumn{2}{|c|}{ Dietary Energy Levels (ME Kcal/kg) } & \multirow[b]{2}{*}{$\mathrm{C}$} \\
\hline & $\overline{\mathrm{A}}$ & $\mathrm{B}$ & \\
\hline Maize & 33.00 & 40.00 & 50.50 \\
\hline Soybean Meal & 18.00 & 17.00 & 20.00 \\
\hline Groundnut Cake & 7.00 & 10.00 & 11.80 \\
\hline Wheat Offal & 39.00 & 27.00 & 11.70 \\
\hline Bone Meal & 3.00 & 3.00 & 3.00 \\
\hline Limestone & 2.00 & 2.00 & 2.00 \\
\hline Common Salt & 0.30 & 0.30 & 0.30 \\
\hline *Premix & 0.25 & 0.25 & 0.25 \\
\hline Methionine & 0.25 & 0.25 & 0.25 \\
\hline Lysine & 0.20 & 0.20 & 0.20 \\
\hline Total & 100.00 & 100.00 & 100.00 \\
\hline \multicolumn{4}{|l|}{ Calculated Analysis } \\
\hline $\mathrm{ME}(\mathrm{Kcal} / \mathrm{kgDM})$ & 2430 & 2602 & 2816 \\
\hline Crude Protein (\%) & 19.80 & 19.70 & 20.20 \\
\hline Lysine $(\%)$ & 1.20 & 1.10 & 1.20 \\
\hline Methionine (\%) & 0.50 & 0.50 & 0.50 \\
\hline Calcium $(\%)$ & 1.60 & 1.60 & 1.60 \\
\hline Phosphorus (\%) & 0.70 & 0.60 & 0.60 \\
\hline Crude Fibre (\%) & 5.40 & 4.70 & 3.90 \\
\hline Ether Extract $\quad(\%)$ & 3.60 & 3.70 & 3.70 \\
\hline
\end{tabular}




\section{Umar and Mohammed}

Experimental animals and their management

A total of 270, One day-old broiler chicks of Cobb 500 strain were purchased from a reputable distributor. The chicks on arrival were weighed and randomly allotted to three treatments coded A, B and C containing 90 birds per treatment, each treatment had three replications of 30 birds. The birds were managed under deep litter system with wood shaving as litter materials. The chickens were vaccinated against Newcastle disease and Gumboro. The pen was cleaned and disinfected using recommended disinfectant (7\% Tar Acid Phenol and 2\% Cresylic Creosote) to avoid microbial contamination.

Routine management was carried out as described by Oluyemi and Roberts (2000). Experimental feed and fresh clean water were provided ad-libitum. The feeding trial lasted for eight weeks $\left(17^{\text {th }}\right.$ February to $13^{\text {th }}$ April, 2016). At the end of the production, 27 birds (three birds per replication) were slaughtered for the preparation of meat floss.

Preparation of spice mixtures for meat floss production

Two spice mixtures (cooking recipe and shredding recipe) were formulated as shown in Tables 3 and 4. The ingredients used for the formulations were purchased from a local spice market within the study area. Each spice was dried and ground separately using a table top grinder (Model BLSTMG. PN133093-002) and the coarse particles removed using a sieve of $1.0 \mathrm{~mm}$ mesh diameter. The cooking and shredding recipes were separately stored in airtight polyvinyl chloride containers for subsequent use.

Table 3: Composition of cooking recipe used for broiler chicken meat floss production (g/100g)

\begin{tabular}{lll}
\hline Ingredients /seasoning & Botanical names & Quantity \\
\hline Common Salt & Sodium Chloride & 10.00 \\
Thyme & Thymus vulgaris L. & 12.50 \\
Curry & Murraya koenigii (L.) Spreng. & 12.50 \\
Onions & Allium cepa L. var. cepa & 50.00 \\
Maggi Cube & *Maggi & 15.00 \\
Total & & $\mathbf{1 0 0 . 0 0}$ \\
\hline
\end{tabular}

Source: Omojola et al., 2014

* Trade name

Table 4: Composition of shredding recipe used for broiler chicken meat floss production (g/100g)

\begin{tabular}{lll}
\hline Ingredients & Botanical names & Quantity \\
\hline Red Pepper & Piper nigrum L. & 35.00 \\
African Nut Meg & Monodora myristica (Gaertn.) Dunal & 2.50 \\
Ginger & Zingiber officinale Rosc. & 4.00 \\
Garlic & Allium sativum L. & 3.00 \\
Cloves & Syzygium aromaticum (L.) Merr. et L.M. Perry & 2.50 \\
Curry Powder & Murraya koenigii L. & 3.50 \\
Thyme Leaves & Thymus vulgaris L. & 2.50 \\
Salt & Sodium Chloride & 5.00 \\
Onions & Allium cepa L. var. cepa & 12.00 \\
Maggi Cube & $*$ Maggi & 30.00 \\
Total & & $\mathbf{1 0 0 . 0 0}$ \\
\hline
\end{tabular}

Source: Omojola et al. (2014)

* Trade name 


\section{Mineral composition of chicken meat floss produced from broilers}

\section{Cooking of meat}

After slaughtering and dressing of the birds, the bones and the muscles were separated; lean meat was cut into pieces of approximately $4 \mathrm{~cm}$ by $2.5 \mathrm{~cm}$ dimension, washed with clean water and mixed with spices. Each meat type was cooked on an adjustable Pifco Japan Electric Hot Plate (Model Number ECP 2002). The cooking recipe was added in the ratio of $1 \mathrm{~g}$ of spice to $100 \mathrm{~g}$ of meat. Four medium-sized (500 g) onions (approximately $50 \mathrm{~g}$ of onions on Dry Matter basis) were thinly sliced and added. Water was added at the ratio of 1.5 liters to $1.0 \mathrm{~kg}$ of meat. The meat samples were cooked to an internal temperature of $72^{\circ} \mathrm{C}$ and the broth was allowed to dry with the meat. The meat samples were removed and allowed to equilibrate to room temperature and weighed.

\section{Meat shredding}

The cooked meat samples were pounded into shreds using a mortar and pestle. The shredding recipe was added in the ratio of 1:20 (50 $\mathrm{g}$ of spice to $1000 \mathrm{~g}$ of meat), while $120 \mathrm{~g}$ onion on dry matter basis was added to every $100 \mathrm{~g}$ of spice used. These were weighed and added a little at a time as pounding progressed for uniform mixing of the recipe.

\section{Frying of meat to form meat floss}

The shredded meat from each meat type was separately shallow fried using stainless steel pot in Soy bean oil (Grand $\left.{ }^{\circledR}\right)$ which was pre-heated to $70{ }^{\circ} \mathrm{C}$. The ratio of oil to meat was 1 liter to $500 \mathrm{~g}$ of meat. The meat samples were fried at 70 strokes per minute (Farouk et al., 2015) until a golden brown colour was obtained (20 minutes). Figure 1 demonstrates chicken meat floss production (Eke et al., 2012).

\section{Oil draining}

The products were poured into a colander after frying and pressure applied to remove excess oil and prevent the final product from sticking. The dry spongy product from each meat type was poured into separately marked flat containers, allowed to cool and separated into strands.

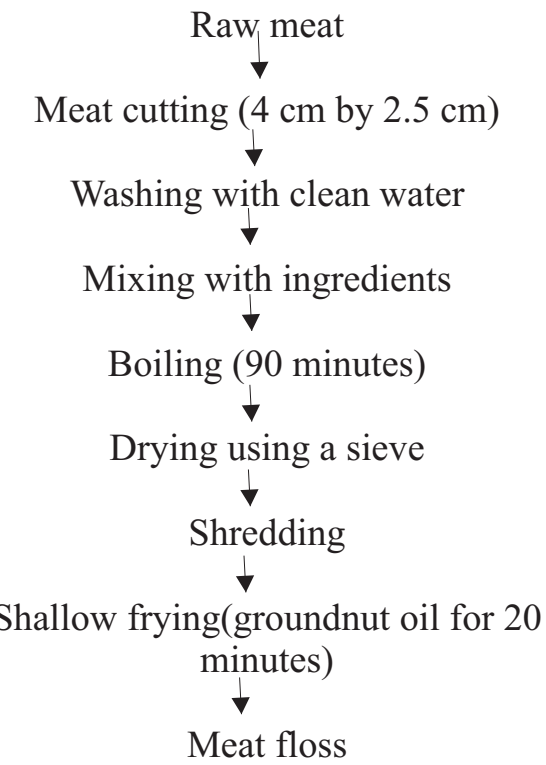

Figure 1: Chicken meat floss preparation. Source: Eke et al., 2012

\section{Sample analyses}

Triplicate samples of the raw and chicken meat were analysed. One gram from each of the three different treatments was inoculated in a vacuum plastic container which was immediately transported to the laboratory for the mineral analysis. After wet digestion, the mineral determined were $\mathrm{Ca}$ and $\mathrm{Mg}$ using Atomic Absorption Spectrophotometer (Buck Scientific Model 210 VGP), while $\mathrm{Na}$ and $\mathrm{K}$ using Flame Photometer.

\section{Data analyses}

Data obtained were subjected to analysis of variance using the General Linear Model Univariate Procedure of SPSS 17.0 and significant differences of means were compared using LSD at 5\% level of probability.

\section{Results}

The results of the macro mineral composition of raw broiler chicken meat fed low energy levels are presented in Table 5 . The raw meat of broiler chicken fed diet 


\section{Umar and Mohammed}

containing 2, $800 \mathrm{ME} \mathrm{Kcal} / \mathrm{Kg}$ had the highest values of $\mathrm{Ca}, \mathrm{Na}$ and $\mathrm{K}$. There was significant difference $(\mathrm{P}<0.05)$ between treatments for $\mathrm{Ca}, \mathrm{Mg}$ and $\mathrm{K}$. The results of the mineral composition of meat floss from broiler chicken fed low energy levels are presented in Table 6 . The meat floss from broiler chicken fed diet containing 2, 800 $\mathrm{ME} \mathrm{Kcal} / \mathrm{Kg}$ had the highest values of $\mathrm{Na}$ and $\mathrm{K}$. The values of $\mathrm{Ca}, \mathrm{Na}$ and $\mathrm{K}$ were lowest in birds fed 2, $600 \mathrm{ME} \mathrm{Kcal/Kg.} \mathrm{Ca,}$ $\mathrm{Mg}$ and $\mathrm{Na}$ recorded significant difference $(\mathrm{P}<0.05)$ between the treatments.

Table 5: Mineral composition of raw broiler chicken meat fed diets with low energy levels

\begin{tabular}{lllll} 
& \multicolumn{4}{c}{ Energy Levels $(\mathrm{ME} \mathrm{Kcal} / \mathrm{Kg})$} \\
\cline { 2 - 5 } Minerals $(\mathrm{Mg} / \mathrm{Kg})$ & 2,400 & 2,600 & 2,800 & $\mathrm{SE}( \pm)$ \\
$\mathrm{Ca}$ & $43.43^{\mathrm{b}}$ & $23.67^{\mathrm{c}}$ & $50.72^{\mathrm{a}}$ & 1.27 \\
$\mathrm{Mg}$ & $22.00^{\mathrm{a}}$ & $18.32^{\mathrm{b}}$ & $16.72^{\mathrm{c}}$ & 1.34 \\
$\mathrm{Na}$ & $30.16^{\mathrm{b}}$ & $30.60^{\mathrm{b}}$ & $48.02^{\mathrm{a}}$ & 1.17 \\
$\mathrm{~K}$ & $32.22^{\mathrm{c}}$ & $41.82^{\mathrm{b}}$ & $80.96^{\mathrm{a}}$ & 1.18 \\
\hline
\end{tabular}

Means with different superscript differ significantly $(\mathrm{P}<0.05)$

Table 6: Minerals composition of meat floss produced from broiler chicken fed diets with low energy levels

\begin{tabular}{lllll}
\hline & \multicolumn{4}{c}{ Energy Levels $(\mathrm{ME} \mathrm{Kcal} / \mathrm{Kg})$} \\
\cline { 2 - 5 } Minerals $(\mathrm{Mg} / \mathrm{Kg})$ & 2,400 & 2,600 & 2,800 & $\mathrm{SE}( \pm)$ \\
$\mathrm{Ca}$ & $102.92^{\mathrm{a}}$ & $56.76^{\mathrm{c}}$ & $80.05^{\mathrm{b}}$ & 1.70 \\
$\mathrm{Mg}$ & $38.84^{\mathrm{b}}$ & $55.73^{\mathrm{a}}$ & $27.58^{\mathrm{c}}$ & 1.50 \\
$\mathrm{Na}$ & $44.42^{\mathrm{b}}$ & $40.63^{\mathrm{c}}$ & $48.69^{\mathrm{a}}$ & 1.24 \\
$\mathrm{~K}$ & $65.24^{\mathrm{b}}$ & $64.67^{\mathrm{b}}$ & $78.81^{\mathrm{a}}$ & 1.36 \\
\hline Means with different superscript differ significantly $(\mathrm{P}<0.05)$ & &
\end{tabular}

\section{Discussion}

Broiler chickens derived the mineral required for normal growth and metabolism from their diets. The biological availability of a mineral from the diet is manifested by the efficiency with which the body utilises and retains the dietary mineral. The retention will be influenced by a number of dietary factors, including diet or ingredient type, source of mineral and, levels and relative proportions of various minerals (Thomas and Ravindran, 2017). Ogunwole et al. (2014) reported $\mathrm{Ca}$ range in raw chicken meat between 29.12 to $33.08 \mathrm{mg} / \mathrm{kg}$ which were within the range found in this research. The work of Eniola et al. (2017) who reported significant differences in $\mathrm{Ca}$ and $\mathrm{Fe}$ between treatments in the raw meat of domesticated and Wild Grass-cutter agrees with this finding. $\mathrm{Ca}, \mathrm{Mg}$ and $\mathrm{Na}$ values of raw meat obtained in this research is in line with the finding of Yasmine (2009). The significant differences $(\mathrm{P}<0.05)$ in $\mathrm{Ca}$ and $\mathrm{Mg}$ values as reported by Ogunwole et al. (2013) were similar to what was reported in this study. The same authors reported $\mathrm{Ca}$ values (33.00 to 35.58 $\mathrm{mg} / \mathrm{kg}$ ) which agrees with the findings of this work. Umar and Muhammad (2011) reported highest values of $\mathrm{K}$ as 71.75 for raw meat, 60.44 for Tsire and $78.06 \mathrm{mg} / \mathrm{Kg}$ for Balangu which was similar to this report. The $\mathrm{Ca}$ value of meat floss obtained from birds fed 2, $400 \mathrm{ME} \mathrm{Kcal} / \mathrm{Kg}$ is relatively similar to what was reported by Jokanovic et al. (2014). The $\mathrm{K}$ content of broiler chicken meat floss in all the treatments is relatively the same with the findings of Umar and Muhammad (2011) who reported 60.44 and $78.06 \mathrm{mg} / \mathrm{Kg}$ for Tsire and Balangu, respectively.

\section{Conclusion}

Raw meat and floss of broiler chickens fed diet containing 2,800 ME $\mathrm{Kcal} / \mathrm{Kg}$ had highest values of $\mathrm{Na}$ and $\mathrm{K}$. 


\section{Mineral composition of chicken meat floss produced from broilers}

\section{References}

Eke, M. O., Ariahu, C. C. and Okonkwo,

T. M. 2012. Production and Quality Evaluation of Dambun-Nama- A Nigerian Dried Meat Product. African Journals Online. 2(30):5766.

Eniola, O., Babatunde, R. O. and Oyelami, B. A. 2017. Comparative Analysis of Nutritional Composition of Meat of Domesticated and Wild Grasscutter (Thryonomys swinderianus). In: Proceedings of the $42^{\text {nd }}$ Annual Conference of the Nigerian Society for Animal Production held at Animal Science Programme, College of Agricultural Science, Landmark University, Omu-Aran, Kwara State, Nigeria.FAO (1988). Food and Agricultural Organisation. Production Year Book. Vol.39. Pp231.

Farouk, M. M., Zhang, S. X. and Cumming, T. 2015. Effect of Muscle Fibre/Fibre Bundle Align Meat on Physical and Sensory Properties of Roasted Beef Steaks. Journal of Muscle foods, 16(3):256273.

Igene, J. O., Farouk, M. M. and Akanbi, C. T. 1990. Preliminary Studies on the Traditionally Processing of Kilishi. Journal of Science, Food and Agriculture, 50:89-98.

Jokanovic, M. R., Tomic, V. M., Jovic, M. T., Skaljak, S. B., Sojic, B. V., Ikonic, P. M. and Tasic, T. A. 2014. Proximate and Minerals Composition of Chicken Giblets from Vojvodina (Northern Serbia). International Journal of Biological, Biomolecular, Agricultural Food and Biotechnological Engineering. 8(9):973-976.

Muhammad, B. F. and Muhammad, A. M. 2007. Effect of Packaging Material and Storage Period on Microbial Load and Organoleptic Properties of Kilishi. Tropical Journal of Animal Science. 10 (1\&2): 217-220.

Ogunwole, O. A., Majekodunmi, B. C., Olowe, T. O. and Olumide, M. D. 2013. Meat Quality and Bone Characteristics of Broiler Chickens fed Diets Supplemented with Graded Levels of Ascorbic Acid. In: Proceedings of the $38^{\text {th }}$ Annual Conference of Nigerian Society for Animal Production held at the Department of Animal Science, Faculty of Agriculture. Rivers State University of Science and Technology, Port-Harcourt, Nigeria.

Ogunwole, O. A., Obo, E. J. and Majekodunmi, B. C. 2014. Chemical Composition of Bone and Meat of Broiler Chicken given Oral Aqueous Vitamin C and Sodium Bicarbonate under Natural Heat Stress. In: Proceedings of the $39^{\text {th }}$ Annual Conference of the Nigerian Society for Animal Production held at Babcock University IlishanRemo, Ogun State, Nigeria.

Oluyemi, J. A. and F. A. Roberts 2000. Feeds and feeding, Poultry Production in Warm Climate (Low Cost Edition). Macmillian Publishers Ltd. London. Pp. 125145.

Omojola, A. B., Kassim, O. R., Olusola, O. O., Adeniji, P. O and Aremo, J. O. 2014. Development and Quality Evaluation of Danbunama (Meat floss) - a Nigerian Shredded Meat Product. 
British Journal of Applied Science \& Technology, 4(26): 3862-3873.

Thomas, D. V. and Ravindran, V. 2017. Mineral Retention in Young Broiler Chicks Fed Diets Based on Wheat, Sorghum or Maize. Poultry Industry Forums.12:312-322.

Umar, A. M. and Muhammad, B. F. 2011. Mineral Composition of Suya offered for Sale at Different Automobile Density Areas of Kano Metropolis. Savannah Journal of Agriculture.6(2): 37-42.
Yasmine, P. D. 2009. Nutrients Composition of Chicken Meat. National Centre of Excellence in Functional Foods, University of Wollongong. Pub. No:8/210. Pp 235.

Received: $12^{\text {th }}$ August, 2018

Accepted: $12^{\text {th }}$ February, 2019 